\title{
KLASIFIKÁCIA POŠKODENIA LESA VO VELKEJ MIERKE NA BÁZE LETECKÝCH MULTISPEKTRÁLNYCH SNÍMOK A LIDAROVÝCH DÁT - PRÍPADOVÁ ŠTÚDIA CHKO DUNAJSKÉ LUHY
}

\author{
Tomáš Goga*, Hana Bobál'ová**, Ivan Sačkov***, Monika Kopecká* \\ * Geografický ústav SAV, Štefánikova 49, 81473 Bratislava, tomas.goga@savba.sk, monika.kopecka@savba.sk \\ ** Univerzita Komenského v Bratislave, Prírodovedecká fakulta, Katedra kartografie, geoinformatiky \\ a dial'kového prieskumu zeme, Ilkovičova 6,84215 Bratislava, stankova@fns.uniba.sk \\ *** Národné lesnícke centrum - Lesnícky výskumný ústav Zvolen, T. G. Masaryka 22, 96092 Zvolen, \\ sackov@nlcsk.org
}

\begin{abstract}
Forest damage classification in large scale based on aerial multispectral images and lidar data: a case study of Dunajské Luhy Protected Landscape Area

Evaluation of forest health conditions is an essential part of forest mapping due to environmental changes in the environment over the last decades. The development of remote sensing technologies creates new possibilities for more effective estimations. The evaluation is performed by estimating the degree of defoliation, and respectively, the depigmentation of assimilation organs of the trees. Based on the relationship between the degree of defoliation as mentioned earlier, and the spectral values, we assume the mathematical relationship between the specified factors. We could also analyse the possibilities of automated methods for defoliation classification. The study deals with methods of calculation of defoliation using 1) a parabolic regression model 2) the Feature Space Optimization tool in eCognition software for object-based image analysis (OBIA) objects and 3) the Support Vector Machine (SVM) classification algorithm for OBIA objects. The research started from the hypothesis that objectbased methods of defoliation computation would achieve more accurate and consistent results than a regression model. The study covered the left bank inundation area of the Danube river with an area of 202,38 hectares. The analysis was based on multispectral aerial photos /IR $(780-880 \mathrm{~nm}), \mathrm{R}(630-680 \mathrm{~nm}), \mathrm{G}(520-590 \mathrm{~nm}) /$ and airborne lidar data (16 points $/ \mathrm{m}^{2}$ total density) obtained on May 2014. Lidar data was converted creating a digital surface model and a raster of intensity using LiDAR Converter Algorithm proceeded to $1 \mathrm{x} 1 \mathrm{~m}$ grid structure. The most accurate results were obtained using the SVM algorithm for OBIA objects. The mean error of the absolute loss of assimilation organs is $9.32 \%$.
\end{abstract}

Key words: defoliation, object-based classification, regression model, SVM algorithm, Feature Space Optimization, Dunajské Luhy Protected Landscape Area

\section{ÚVOD}

Na území Slovenska pokrývajú lesy viac ako dva milióny hektárov (približne $41 \%$ rozlohy SR). Na základe analýz údajov CORINE Land Cover sa lesná krajina v uplynulých dvoch desat'ročiach vyznačovala najrozsiahlejšími zmenami krajinnej pokrývky v rámci SR (Feranec et al. 2018). Okrem antropogénnych zásahov sú príčinou zmien aj prírodné hrozby - kalamitné víchrice, dlhotrvajúce obdobia sucha spojené so zvýšeným rizikom lesných požiarov a aktivizácia biotických škodcov. Tieto hrozby zintenzívňujú požiadavky na získavanie a vyhodnocovanie aktuálnych informácií o stave lesa, čo je základným predpokladom pre návrh optimálnych manažmentových opatrení (Bucha et al. 2014). 
V SR, podobne ako $\mathrm{v}$ iných európskych krajinách, bol v uplynulom období zaznamenaný výrazný nárast zhoršeného zdravotného stavu lesov. Kunca et al. (2018) konštatujú, že zdravotný stav ihličnatých porastov bol v roku 2017 najhorším za celé obdobie štatistického zist'ovania výskytu škodlivých činitel'ov (1960 - 2017).

Údaje z dial'kového prieskumu Zeme predstavujú vhodný materiál na sledovanie zdravotného stavu lesov na európskej úrovni (UN-ECE ICP Forest 2006), ako aj na úrovni štátov $\mathrm{v}$ rámci monitoringu zdravotného stavu lesných porastov (Pavlenda et al. 2014).

Hodnotenie zdravotného stavu lesných porastov sa vykonáva najmä odhadom stupňa defoliácie, resp. depigmentácie asimilačných orgánov stromov. Klasifikáciu poškodenia lesných porastov môžeme realizovat's využitím multispektrálnych satelitných snímok - Landsat Sentinel a i. (Bucha a Vladovič, 2000, Bucha et al. 2014, Adelabu et al. 2014 a Hawryła et al. 2018); leteckých multispektrálnych snímok (Račko 1996, Bucha a Slávik 2013 a Eigirdas et al. 2013) alebo aj pomocou modernejších snímacích systémov - napr. LIDAR (Barnes et al. 2017 a Sedliak et al. 2017).

Hlavnými indikátormi pri klasifikácii poškodenia lesných porastov je výskyt suchárov alebo vel'mi poškodených stromov identifikovaných vizuálnou klasifikáciou a defoliáciou (stratou asimilačných orgánov), ktorá sa vyhodnocuje pomocou metód digitálnej klasifikácie (Bucha a Vladovič 2000). Defoliácia môže byt' spôsobená viacerými stresovými faktormi (obdobie sucha, znížená hladina podzemnej vody a pod.). Vplyv stresových faktorov má v konečnom dôsledku dosah na bunkovú štruktúru a následnú interakciu spektrálnej odrazivosti s bunkovou štruktúrou, príp. chlorofylom (Račko 1996, Gross 2000 a Bucha et al. 2014).

Podl'a bunkovej analýzy listov (Račko 1996) najvýraznejšie reaguje na zmeny infračervené spektrum. S využitým tejto časti spektra možno identifikovat' aj začínajúcu defoliáciu, ked’že nižší obsah chlorofylu v asimilačných orgánoch zapríčiňuje vysokú odrazivost'. Množstvo karoténov (červený pigment) a množstvo xantofylov (žltý až červeno-fialový pigment) súvisí s reakciou na stresové zat’aženie porastu. Strata chlorofylu spôsobená deteriorizáciou chloroplastov spôsobuje žltnutie listov (Szekielda 1988 a Kmet' a Blaho 1996). Maximálna odrazivost' vo viditel'nom spektre sa preto presúva zo zeleného do červeného pásma, čo sa využíva pri tvorbe červeno-zeleného vegetačného indexu (Wulder et al. 2008).

Matematická závislost' medzi hodnotou defoliácie a spektrálnymi vlastnost’ami je založená na zápornej závislosti, ked’že znížením množstva chlorofylu v asimilačných orgánoch dochádza k zvyšovaniu hodnoty defoliácie. Táto závislost' sa mení podl'a druhu skúmanej dreviny. Podl'a Račka (1996) úroveň chlorofylu v asimilačných orgánoch je nositel'om informácie o poškodení asimilačných orgánov a teda nositel’om informácie o výslednej defoliácii. Tento vzt’ah potvrdili vo svojej práci Šmelko (1990) aj Scheer (1997) uplatnením dvojfázového regresného výberu na príklade klasifikácie poškodenia smrekových porastov. Vhodnost' postupu preukázali aj Ekstrand et al. (1998), pričom jeho využitie nachádzame aj v prácach zaoberajúcich sa klasifikáciou poškodenia a aplikáciou v rámci hospodárskej úpravy lesov (Bucha a Vladovič 2000, Bucha et al. 2013 a Bucha et al. 2014).

Ďalšou metódou na mapovanie defoliácie sú klasifikačné objektovo orientované metódy (OBIA) v rámci mapovania krajinnej pokrývky (Gábor et al. 2017) alebo lesníckeho mapovania (Bucha et al. 2013). Obraz klasifikovaný takýmito me- 
tódami poskytuje ucelenejšie výsledky tak, že hodnotí homogénne skupiny pixelov. Tie nemusia obsahovat' iba spektrálne informácie, ale aj vybrané charakteristiky: tvar, vel'kost', priestorové vzt'ahy, resp. textúru (Jensen 1986 a Lillesand et al. 2014). Vhodné sú na delineáciu korún jednotlivých stromov, najmä v kombinácii s lidarovými dátami (napr. Tiede et al. 2005, Chen et al. 2006 a Barnes et al. 2017).

Postupom pri využití objektovo orientovaného prístupu ku klasifikácii objektov OBIA s využitím nástroja Feature Space Optimization (FSO) v prostredí eCognition sa zaoberajú Tarantino a Figorito (2012). Podl'a Jensena (1986) je selekcia vhodných spektrálnych pásiem alebo obrazových dát klúčovým krokom $\mathrm{k}$ d'alšej obrazovej analýze. Problémom súvisiacim s využívaním nástroja FSO sa vo svojej práci venovali aj Laliberte et al. (2010), ktorí poukazujú na potrebu správneho výberu jednotlivých vstupných spektrálnych pásiem alebo údajov. Herold et al. (2003) a Marpu et al. (2008) dokumentujú možnosti testovania aj iných spektrálnych vzdialeností - napríklad využitie Bray-Curtisovho indexu rozdielnosti.

Inou metódou na klasifikáciu defoliácie môže byt' aj využitie klasifikačného algoritmu SVM (Support Vector Machine). Jeho princípom je nájdenie najlepšieho lineárneho separátora trénovacích údajov. Podl'a Vapnika (2013) je optimálny separátor taký, ktorého lineárna separátna rovina je čo najd’alej od dvoch tried. Táto optimalizácia je závislá od bodov najbližších k druhej triede, nazývaných pomocné vektory. Algoritmus však dokáže klasifikovat' len dve triedy a len lineárne. Problematickou je preto oblast' klasifikácie viacerých tried, ked'že na základe ich komplexnosti a počtu nie je možné klasifikovat' ich lineárne. Tento problém rieši algoritmus SVM využívaním jadrovej funkcie (ang. kernel function), čím vytvára nelineárnu transformáciu (Baghdadi a Zribi 2016).

Hawryła et al. (2018) analyzovali defoliáciu borovice lesnej (Pinus sylvestris) využitím troch klasifikačných algoritmov - SVM, RF (angl. Random Forest) a kNN (angl. k-nearest neighbors). Napriek porovnatel'ným výsledkom považujú algoritmus SVM za najstabilnejší pre daný typ klasifikácie. Adam et al. (2014) aj Ghosh et al. (2014) pri porovananí algoritmov SVM a RF nezistili žiadne štatisticky významné odchýlky. Napriek tomu Féret a Asner (2013) považujú algoritmus SVM za vhodnejší najmä pre efektívnu optimalizáciu vstupných parametrov. Analýzou vybraných algoritmov sa zaoberali aj Sothe et al. (2017), Otsu et al. (2018) a Thanh a Kappas (2018), ktorí porovnávali algoritmy Support Vector Machine (SVM), Random Forest (RF) a k-Nearest Neighbor $(\mathrm{kNN})$ pri hodnotení defoliácie lesných porastov.

Z hl'adiska metodického prístupu je pri klasifikačných algoritmoch dôležité testovat' vplyv využitia vegetačných indexov na výsledky klasifikácie, ked’že vegetačné indexy je možné podl’a Gamona et al. (1995) použit' ako biofyzikálny indikátor. Využitím vegetačných indexov pri analýze štruktúry lesného porastu sa zaoberali Freitas et al. (2005).

Ciel'om príspevku je porovnanie efektívnosti využitia a správnosti troch rôznych automatizovaných metód určovania zdravotného stavu lesných porastov. Podnetom na realizáciu predmetnej štúdie bola potreba získat' prehl'ad o efektívnosti používaných metód $\mathrm{v}$ lesníckom výskume. Na rozdiel od uvedených komparatívnych štúdií do porovnania zahŕňame aj komplexnejšiu analýzu s využitím štatistickej pixelovo orientovanej metódy a jej porovnania s automatizovanými metódami na objektoch OBIA. Ide o metódy výpočtu defoliácie: 1) s využitím regresného modelu, 2) na objektoch OBIA s využitím nástroja FSO v prostredí eCognition a 
3) s využitím klasifikačného algoritmu SVM na objektoch OBIA. Čiastkovým ciel'om je analýza využitel'nosti Bray-Curtisovej podobnosti pri tvorbe trénovacích množín. Vychádzame z hypotézy, že objektovo orientované metódy výpočtu defoliácie budú dosahovat’ presnejšie a ucelenejšie výsledky ako metóda s využitím regresného modelu.

\section{ZÁKLADNÁ CHARAKTERISTIKA ZÁUJMOVÉHO ÚZEMIA}

Záujmové územie sa nachádza v oblasti l’avostrannej inundácie Dunaja v katastrálnom území obce Baka v okrese Dunajská Streda, pričom jeho juhozápadná čast' zasahuje na územie obce Lipót v Rábsko-mošonsko-šopronskej župe na území Mad'arska (obr. 1). Celková rozloha územia je 202,38 hektára. Nachádza sa v CHKO Dunajské luhy medzi Bodíckym a Bačianskym ramenom v časti s rozsiahlymi komplexmi lužných lesov a aluviálnych lúk, ktoré patria medzi najzachovalejšie lokality v celej oblasti. Typickými sú rozsiahle komplexy lužných lesov a aluviálnych lúk.

Podl'a hospodárskych súborov lesných typov sa tu nachádzajú stanovištia zodpovedajúce prechodným luhom. Podl'a lesníckej typizácie ide o dubové lužné jaseniny a brestové lužné jaseniny (prechodné luhy), vŕbové topoliny (mäkké luhy), hrabové lužné jaseniny (tvrdé luhy). V drevinovom zložení v sledovanej oblasti prevládajú šl'achtené topole (Populus sp.), topole domáce (Populus nigra L. a $P$. alba L.), vŕby (Salix alba, S. fragilis L.) a jasene (najmä Fraxinus angustifolia Vahl).

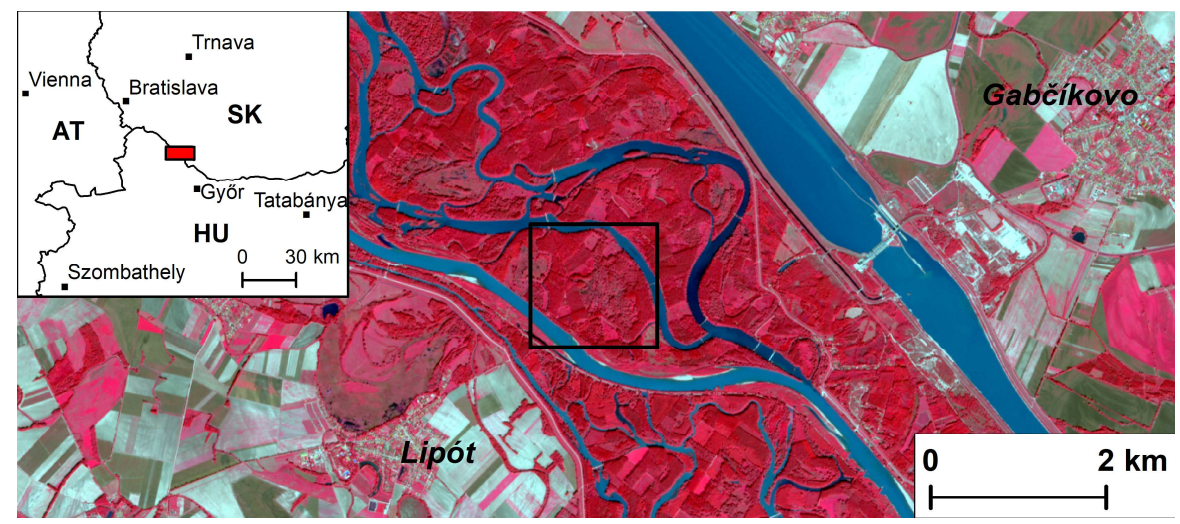

Obr. 1. Lokalizácia záujmového územia

Zdroj: Sentinel-2, 09/2018

\section{VSTUPNÉ ÚDAJE}

Ako vstupné údaje boli využité letecké multispektrálne snímky a záznamy leteckého laserového skenovania. Letecké snímkovanie bolo realizované $\mathrm{v}$ dňoch 21. - 22. 5. 2014. Snímkovacie zariadenie bola kamera LeicaRCD30. Priemerná výška letu bola $1293 \mathrm{~m}$. Pre účely tejto štúdie bol poskytnutý výrez v 8-bitovom rozlíšení, vo formáte TIF s vel'kost'ou obrazového prvku $50 \times 50 \mathrm{~cm}$ v súradnicovom systéme s EPSG označením 32633 (WGS84 - UTM 33). Dodané boli tri spektrálne pásma: infračervené (IR), červené $(R)$ a zelené $(G)$. 
Údaje leteckého laserového skenovania boli objednávatel'ovi dodané vo formáte .LAS (v. 1.2). Dátum skenovania je zhodný s dátumom leteckého snímkovania. Skenovacím zariadením bolo zariadenie Leica ALS 70-CM. Hustota všetkých bodov na výreze záujmového územia bola 16 bodov $/ \mathrm{m}^{2}$. Súradnicový systém dodanej vrstvy bol WGS84 - UTM33.

Spracovanie leteckých laserových údajov bolo vykonané v prostredí eCognition Developer s využitím nástroja LiDAR Converter Algorithm, filtrované na báze prvého odrazu a celkového počtu odrazov a interpolované metódami priemerného susedstva matice $5 \times 5$. Výstupom uvedeného spracovania bol digitálny model povrchu - DSM (angl. Digital Surface Model) a raster intenzity odrazov - hodnoty v pixeloch obsahujú počet zaregistrovaných odrazov laserového lúču v danom pixely.

\section{METODIKA}

Metodický postup pozostával z nasledovných krokov, ktoré sú podrobne sú popísané v jednotlivých podkapitolách:

- Vizuálna interpretácia defoliácie stromov;

- Odvodenie optimalizovaných komponentov;

- Výpočet defoliácie s využitím regresného modelu;

- Výpočet vegetačných indexov;

- Segmentácia obrazu;

- Výpočet defoliácie s využitím s využitím nástroja FSO;

- Výpočet defoliácie s využitím klasifikačného algoritmu SVM na objektoch OBIA a

- Tvorba masky lesa.

\section{Vizuálna interpretácia defoliácie stromov}

V prvej fáze regresného výberu sa získavajú údaje o samotnej defoliácii stromov $\mathrm{v}$ rámci monitorovaného územia $\mathrm{v}$ zmysle metodiky programu UN-ECE ICP Forest (2006). Na interpretáciu defoliácie stromov bol využitý výberový interpretačný kl'úč vypracovaný Grossom (2000) pre potreby Európskej komisie, s využitím prípadovej štúdie Fagus sylvatica, ked’že táto drevina má spektrálne vlastnosti najviac podobné drevinovému zloženiu v záujmovej oblasti. Hodnotené koruny boli začlenené do desiatich kategórií defoliácie podl'a percentuálnej straty asimilačných orgánov.

\section{Odvodenie optimalizovaných komponentov}

Druhú fázu dvojfázového regresného výberu podl’a Scheera (1997) predstavuje špecifická ortogonálna transformácia spektrálnych pásiem - Gramm-Schmidt transformácia (GST). Matematický podklad pre tento typ transformácie spracoval Jackson (1983). Ciel'om tejto transformácie je nájst' optimálne transformačné koeficienty na klasifikáciu poškodenia lesného porastu pre zvolenú kombináciu kanálov. Špecifický postup pri aplikácii tohto typu transformácie zvolili Bucha a Slávik (2013) pre odhad defoliácie v oblasti Gabčíkova.

Rozdiely medzi prístupmi prezentovanými v týchto dvoch štúdiách sú vo fyzikálnom význame odvodených komponentov. V prístupe Jacksona (1983) primárne 
odvodený komponent (NSC1 - New Synthetic Component) predstavuje jas a sekundárne odvodený komponent (NSC2) množstvo zelene. V prístupe prezentovanom Buchom a Slávikom (2013) primárny komponent minimalizuje spektrálnu variabilitu drevinového zloženia porastu. Sekundárny komponent NSC2 je optimalizovaný pre zvýraznenie poškodenia, resp. defoliácie.

Upravené matematické definície podl'a postupu aplikovaného Buchom a Slávikom (2013) sú definované vzt’ahmi (1) a (2).

$$
N S C 1=A_{1,1} * X_{1}+A_{1,2} * X_{2}+A_{1,3} * X_{3}+A_{1,4} * X_{4} \text {, }
$$

kde $A_{1, \mathrm{i}}$ sú hl'adané koeficienty pre odvodenie komponentu $N S C 1$ a $X_{\mathrm{i}}$ sú spektrálne hodnoty pixelu používaného spektrálneho kanála.

$$
N S C 2=A_{2,1} * X_{1}+A_{2,2} * X_{2}+A_{2,3} * X_{3}+A_{2,4} * X_{4} \text {, }
$$

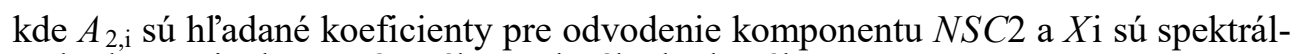
ne hodnoty pixelu používaného spektrálneho kanála.

Hodnoty sekundárneho komponentu NSC2 prestavujú kolmú vzdialenost' medzi hodnotami plne olisteného, nepoškodeného porastu, predstavenými v rámci primárneho komponentu NSC1. Vzdialenost' medzi hodnoteným stromom a líniou poškodenia je priamo úmerná (Bucha a Slavík 2013).

Do matematického výpočtu primárneho a sekundárneho komponentu vstupovali tri spektrálne kanály - IR $(780-880 \mathrm{~nm}), \mathrm{R}(630$ - $680 \mathrm{~nm})$ a G $(520$ - $590 \mathrm{~nm})$. Vzhl'adom na problematické určovanie drevinového zloženia z leteckých snímok v danej lokalite boli pri drevinovej vegetácii rozlišované len dve triedy: „spektrálne svetlé stromy“ (SSS) a „spektrálne tmavé stromy“ (STS). Teoretickým predpokladom je, že trieda SSS reprezentuje stromy s vysokými hodnotami spektrálnej odrazivosti, akými sú napríklad Salix alba alebo Populus alba. Naopak, predpokladanými drevinami v triede STS sú dreviny ako Populus nigra. Výsledkom zberu týchto spektrálnych vzoriek boli priemerné spektrálne hodnoty v jednotlivých triedach, ktoré vstupovali do výpočtu komponentu NSC1.

Komponent NSC2 je výsledkom vylepšenia NSC1 komponentu tak, aby sa $\mathrm{s}$ jeho pomocou dal odhadnút' stupeň poškodenia koruny, resp. stupeň jej defoliácie. Táto operácia prebiehala na základe zozbieraných spektrálnych hodnôt poškodených stromov. Vypočítaná priemerná spektrálna hodnota poškodených korún je základným prvkom pri výpočte NSC2 komponentu.

\section{Výpočet defoliácie s využitím regresného modelu}

Na výpočet defoliácie pre celé sledované územie je potrebné prepojit' identifikované plochy defoliácie s vytvoreným komponentom NSC2. Prepojenie prvej a druhej fázy dvojfázového regresného výberu sa vykonáva pomocou metód regresnej analýzy (Goga a Bobál'ová (2017).

Vstupnými hodnotami do regresného výberu sú párové hodnoty defoliácie s hodnotami spektrálnej odrazivosti z optimalizovaného komponentu NSC2. Na základe uvedeného preto za závislú premennú považujeme hodnotu defoliácie v percentách a za nezávislú premennú hodnotu komponentu NSC2.

Goga a Bobál'ová (2017) špecifikovali vhodný typ regresnej funkcie na výpočet defoliácie v sledovanom záujmovom území, na základe čoho sme pre výpočet defoliácie využili predpis parabolickej regresnej funkcie podl'a vzt’ahu (3), kde $\beta_{0-2}$ predstavujú jednotlivé koeficienty parabolickej funkcie a $x / y$ jednotlivé premenné. 


$$
y=\beta_{0}+\beta_{1} x+\beta_{2} x^{2}
$$

Výpočet vegetačných indexov

Vstupné tri spektrálne pásma boli použité na výpočet štyroch vegetačných indexov. Vegetačné indexy odvodené $\mathrm{v}$ tejto časti predstavujú vstup do klasifikačných algoritmov:

- Simple Ratio $(S R)$, ktorého hodnoty rastú v prípadoch vyššieho množstva zelenej vegetácie obsiahnutej v pixeli (Jordan 1969) - vzt'ah (4):

$$
S R=\frac{\rho_{\text {NIR }}}{\rho_{\text {Red }}}
$$

- Normalized Difference Vegetation Index (NDVI) zobrazuje mieru nadzemného množstva živej biomasy, pričom najvyššie hodnoty zodpovedajú hustej zelenej vegetácii (Rouse et al. 1974 a Grădinaru et al. 2017) - vzt’ah (5):

$$
N D V I=\frac{\rho_{N I R}-\rho_{\text {Red }}}{\rho_{N I R}+\rho_{\text {Red }}}
$$

- Green-Red Vegetation Index (GRVI) použivaný na identifikáciu zelenej vegetácie medzi inými povrchmi; vel'mi signifikantné výsledky vykazuje pri identifikácii jarného pučania listov a jesenného hnednutia listov (Motohka et al. 2010) vzt'ah (6):

$$
G R V I=\frac{\rho_{\text {Green }}-\rho_{\text {Red }}}{\rho_{\text {Green }}+\rho_{\text {Red }}}
$$

Green Chlorophyll Index $\left(C_{\text {Green }}\right)$ je odvodený z koncepčného modelu recipročnej odrazivosti, ktorá umožňuje izoláciu koeficientu pigmentu zo spektra odrazivosti; vel'mi vhodný pre hrubú primárnu produkciu plodín (Gitelson et al. 2005) vztah (7).

$$
C I_{\text {Green }}=\frac{\rho_{\text {NIR }}}{\rho_{\text {Green }}}-1
$$

\section{Segmentácia obrazu}

Tento proces predstavuje základný vstup do výpočtu defoliácie. Podstatou je segmentácia obrazu na základné objekty - dostatočne malé a kompaktné, ktoré by $\mathrm{v}$ ideálnom prípade vystihovali tvar koruny.

Segmentácia obrazu prebiehala v prostredí eCognition Developer s využitím algoritmu viacúrovňovej segmentácie (multiresolution segmentation). V procese segmentácie obrazu pri tvorbe základných objektov boli použité parametre uvedené $\mathrm{v}$ tab. 1. Použité segmentačné parametre boli zvolené experimentálnym spôsobom. V rámci procesu bola využitá tematická vrstva hodnotených korún z procesu vizuálne interpretácie defoliácie stromov, ktorá obsahovala dôsledne interpretovaný tvar korún. 
Tab. 1. Nastavenia segmentačných parametrov pri tvorbe základných objektov

\begin{tabular}{cccc}
\hline & \multicolumn{3}{c}{ Nastavenia } \\
\hline & & Digital Surface Model - prvý odraz & 5 \\
& & Raster intenzity odrazov & 5 \\
& Váhy obrazových vrstiev & $\mathrm{IR}$ & 4 \\
Viacúrovňová & $\mathrm{R}$ & 3 \\
segmentácia & $\mathrm{G}$ & 3 \\
\cline { 2 - 4 } & & \multicolumn{2}{c}{ áno } \\
\cline { 2 - 4 } & Využitie tematickej vrstvy & mierka & 13 \\
& \multirow{2}{*}{ Parametre } & tvar & 0,4 \\
& & kompaktnost' & 0,9 \\
\hline
\end{tabular}

Výpočet defoliácie s využitím nástroja FSO

Prostredie eCognition Developer poskytuje $\mathrm{v}$ rámci optimalizačných metód priestorových funkcií nástroj Feature Space Optimization (FSO). Tento nástroj porovnáva vlastnosti vybraných tried s maticou kombinačných funkcií. Vyhl'adáva tak najvyššiu priemernú minimálnu vzdialenost' medzi trénovacími vzorkami (samples). Jeho výsledkom je vypočítaná euklidovská vzdialenost' založená na trénovacích vzorkách všetkých tried pre rôzne kombinácie vrstiev. Vyberá takú kombináciu prvkov, ktorá má najvhodnejšiu vzdialenost’ou medzi triedami. Nevýhodou v tomto procese je nejasné určovanie poradia vrstiev pri vytváraní kombinácií.

Pre trénovacie vzorky sú vypočítané objektové štatistiky z tých vrstiev, ktoré vykazovali najväčšiu spektrálnu odlišnost'. Tieto vzorky sa následne využívajú na klasifikáciu defoliácie pre všetky vytvorené objekty na základe klasifikačnej metódy najbližších susedov.

Výpočet defoliácie s využitím klasifikačného algoritmu SVM na objektoch OBIA

Algoritmus SVM (Support Vector Machine) predstavuje algoritmus kontrolovanej klasifikácie vyžadujúci vstup trénovacích plôch. Ich štatistickú vhodnost' sme testovali s využitím všetkých dostupných dátových vrstiev. Použitou spektrálnou vzdialenost'ou bol index Bray-Curtisovej podobnosti (Bray a Curtis 1957) definovanej vzt'ahom (8).

$$
S(x, y)=B C_{x y}=100-\left(\frac{\sum_{k=1}^{n}\left|x_{k}-x_{k}\right|}{\sum_{k=1}^{n}\left(x_{k}+x_{k}\right)}\right) * 100,
$$

kde $x$ je prvý spektrálny vektor klasifikačnej triedy, $y$ je druhý spektrálny vektor klasifikačnej triedy a $n$ je počet spektrálnych kanálov.

Bray-Curtisov index podobnosti bol aplikovaný pre desat' klasifikačných tried reprezentovaných defoliačnými kategóriami a 13 údajových vrstiev zastúpených vstupnými údajmi alebo $\mathrm{z}$ nich odvodenými komponentami. Proces prebiehal pre všetky možné kombinácie kategórií bez opakovania a zároveň pre všetky možné kombinácie dátových vrstiev podla jednotlivých dimenzií, ktoré predstavujú celkový počet použitých tried $\mathrm{v}$ danom výpočtovom kroku.

Pri klasifikácii objektov OBIA bol využitý algoritmus SVM implementovaný v module pre SVM klasifikáciu v prostredí SAGA GIS (Chang 2011). Po optimali- 
zácii výpočtových časov bol použitý C-SVC typ polynomiálnej kernelovej funkcie. Využitie polynomiálnej kernelovej funkcie sme uplatnili, ked’že podl'a nášho názoru nebolo možné rovinu trénovacích vzoriek rozdelit' lineárne v dvojrozmernej rovine dát. Nelineárna kernelová funkcia vytvára trojdimenzionálny priestor a tým umožňuje aplikáciu algoritmu SVM.

\section{Tvorba masky lesa}

Procesom tvorby masky lesa sa nazýva proces odlíšenia lesa od ostatných kategórií krajinnej pokrývky. Vo výsledku odlišujeme lesné plochy a ostatné kategórie, ktoré z hl'adiska ciel'a práce nazývame nelesné plochy (NLP). Na základe zaužívaných lesníckych postupov považujeme za lesné plochy (LP) iba také plochy, ktorých výška zapojeného porastu dosahuje aspoň pät' metrov.

Maska lesa bola vytvorená objektovo orientovaným prístupom v prostredí eCognition Developer s využitím algoritmov dvoch krokov viacúrovňovej a jedného kroku kontrastnej segmentácie. Takto vygenerovaná maska lesa bola doplnená posledným krokom viacúrovňovej segmentácie s využitím odvodeného komponentu NSC1.

V procese je potrebné charakterizovat' parametre segmentácie a zároveň aj prahové hodnoty použité v prípade klasifikátorov. Použitým klasifikátorom bol prirad'ovací algoritmus (assing class algorithm). Nastavenia segmentačných parametrov, resp. použité prahové hodnoty, boli experimentálne zvolené a vizuálne testované (tab. 2, resp. tab. 3).

Presnost' výslednej masky lesa bola vyhodnotená pomocou klasifikačnej chybovej matice a kappa koeficientu na vygenerovanej pravidelnej mriežke obsahujúcej 300 bodov. Každý z daných bodov bol samostatne vizuálne klasifikovaný pre potreby vyhodnotenia.

Tab. 2 Nastavenia segmentačných parametrov v procese tvorby masky lesa

\begin{tabular}{|c|c|c|c|c|c|}
\hline \multirow{2}{*}{ Segmentácia } & & \multirow{2}{*}{ Nastavenia } & \multicolumn{3}{|c|}{ Úroveň } \\
\hline & & & 1 & 2 & aplikácia NSC1 \\
\hline \multirow{9}{*}{$\begin{array}{l}\text { Viacúrovňová } \\
\text { segmentácia }\end{array}$} & \multirow{6}{*}{$\begin{array}{c}\text { Váhy } \\
\text { obrazových } \\
\text { vrstiev }\end{array}$} & DSM - prvý odraz & 15 & 15 & 0 \\
\hline & & Raster intezity odrazov & 10 & 10 & 0 \\
\hline & & IR & 1 & 1 & 0 \\
\hline & & $\mathrm{R}$ & 1 & 1 & 0 \\
\hline & & G & 1 & 1 & 0 \\
\hline & & $\mathrm{NSC} 1$ & 0 & 0 & 10 \\
\hline & \multirow{3}{*}{ Parametre } & mierka & 200 & 30 & 5 \\
\hline & & tvar & 0,2 & 0,2 & 0,1 \\
\hline & & kompaktnost' & 0,7 & 0,5 & 0,1 \\
\hline \multirow{8}{*}{$\begin{array}{l}\text { Kontrastná } \\
\text { segmentácia }\end{array}$} & \multicolumn{2}{|c|}{ minimálna hodnota šede } & \multicolumn{3}{|c|}{0} \\
\hline & \multicolumn{2}{|c|}{ maximálna hodnota šede } & \multicolumn{3}{|c|}{255} \\
\hline & \multicolumn{2}{|c|}{ segmentačná obrazová vrstva } & \multicolumn{3}{|c|}{ IR } \\
\hline & \multirow{2}{*}{ Triedy } & svetlé objekty & & les & \\
\hline & & tmavé objekty & & nelesná plocha & \\
\hline & \multicolumn{2}{|r|}{ kontrastný mód } & \multicolumn{3}{|c|}{ edge ratio } \\
\hline & \multirow{2}{*}{$\begin{array}{l}\text { minimálna } \\
\text { rozloha }\end{array}$} & svetlé plochy & \multicolumn{3}{|c|}{0,2} \\
\hline & & tmavé plochy & \multicolumn{3}{|c|}{0,3} \\
\hline
\end{tabular}


Tab. 3. Prahové hodnoty použité v klasifikačných algoritmoch podl’a úrovní

\begin{tabular}{cccc}
\hline Úroveň & Vstupná trieda & Vztah & Výstupná trieda \\
\hline \multirow{2}{*}{1} & neklasifikované & počet odrazov $<=1,3$ & NLP \\
& neklasifikované & IR $<60$ & NLP \\
\multirow{2}{*}{2} & neklasifikované & počet odrazov $<=1,73$ & NLP \\
& neklasifikované & IR $<60$ & NLP \\
\hline \multirow{2}{*}{ Aplikácia NSC1 } & LP & NSC $1<33$ & NLP \\
& LP & IR $<83$ & NLP \\
\hline
\end{tabular}

\section{VÝSLEDKY}

Vizuálna interpretácia defoliácie korún

Základný vstup v rámci nášho príspevku predstavujú údaje získané vizuálnou interpretáciou defoliácie 77 korún stromov (tab. 4).

Tab. 4. Sumárne výsledky hodnotených korún stromov s určeným stupňom defoliácie

\begin{tabular}{ccccc}
\hline $\begin{array}{c}\text { Kategória } \\
\text { defoliácie }\end{array}$ & $\begin{array}{c}\text { Strata asimilačných } \\
\text { orgánov v \% }\end{array}$ & $\begin{array}{c}\text { Počet hodnotených } \\
\text { korún }\end{array}$ & $\begin{array}{c}\text { Podiel pixelov } \\
\text { v triede } \mathrm{v} \%\end{array}$ & Trieda poškodenia \\
\hline 1 & $0-10$ & 25 & 26 & bez poškodenia \\
2 & $11-20$ & 11 & 12 & slabé poškodenie \\
\hline 3 & $21-30$ & 4 & 5 & stredné poškodenie \\
4 & $31-40$ & 7 & 8 & silné poškodenie \\
\hline 5 & $41-50$ & 8 & 12 & odumreté stromy \\
6 & $51-60$ & 8 & 17 & \\
\hline 7 & $61-70$ & 6 & 10 & \\
\hline 9 & $71-80$ & 1 & 1 & \\
\hline Spolu & $81-90$ & 1 & 100 & \\
\hline
\end{tabular}

Výpočet optimalizovaných komponentov pre automatickú klasifikáciu

Predpokladom pre odvodenie optimalizovaného komponentu NSC1 je zozbieranie spektrálnych charakteristík v rámci triedy SSS a STS. Celkovo bolo zozbieraných 59 vzoriek, z toho 31 vzoriek v triede SSS a 28 vzoriek v triede STS. Experimentálne bola overená aj požadovaná výrazná spektrálna odlišnost’ zozbieraných vzoriek.

V zmysle lesníckej terminológie UN-ECE ICP Forests (2006) za poškodené stromy považujeme také stromy, ktorých strata asimilačných orgánov presiahne $60 \%$. Na základe tohto vstupovalo do procesu odvodzovania NSC2 komponentu na výpočet priemernej spektrálnej hodnoty 16 poškodených stromov, ktorých stupeň defoliácie bol odhadnutý pri vizuálnom hodnotení defoliácie. 
Výsledný tvar NSC komponentov je uvedený vo vzt'ahoch (9) a (10).

$$
\begin{aligned}
& N S C 1=0,20319 * I R+0,66795 * R+0,71593 * G \\
& N S C 2=-0,97672 * I R+0,18961 * R+0,10031 * G,
\end{aligned}
$$

kde IR je infračervené pásmo, $R$ je červené pásmo a $G$ je zelené pásmo.

\section{Hodnotenie správnosti tvorby masky lesa}

Analýza presnosti binárnej rastrovej masky lesa na vzorke 300 bodov preukázala celkovú presnost' 95,33 \%, pričom kappa koeficient dosiahol hodnotu 0,901.

\begin{tabular}{|c|c|c|c|c|c|c|}
\hline \multicolumn{5}{|c|}{ Referenčné údaje } & \multirow{2}{*}{$\begin{array}{l}\text { Nadhodnotenie } \\
(\%)\end{array}$} & \multirow{2}{*}{$\begin{array}{c}\text { Užívatel'ská } \\
\text { správnost' (\%) }\end{array}$} \\
\hline & Kategória & Lesné plochy & $\begin{array}{l}\text { Nelesné } \\
\text { plochy }\end{array}$ & $\Sigma$ & & \\
\hline \multirow{3}{*}{$\begin{array}{l}\text { Klasifikované } \\
\text { údaje }\end{array}$} & Lesné plochy & 108 & 12 & 120 & 10,00 & 90,00 \\
\hline & Nelesné plochy & 2 & 178 & 180 & 1,11 & 98,89 \\
\hline & $\Sigma$ & 110 & 190 & 300 & & \\
\hline \multicolumn{2}{|c|}{ Podhodnotenie (\%) } & 1,82 & 6,32 & & 4,67 & \\
\hline \multicolumn{2}{|c|}{ Producentská správnost’ (\%) } & 98,18 & 93,68 & & & 95,33 \\
\hline \multicolumn{2}{|c|}{ Kappa koeficient } & & & 0,9 & & \\
\hline
\end{tabular}

Tab. 5. Klasifikačná chybová matica a kappa koeficient pre masku lesa

Porovnanie efektívnosti využitia vybraných metód určovania zdravotného stavu porastov

Ako regresný model sme si na základe práce Gogu a Bobál'ovej (2017) zvolili parabolický predpis. Odvodený regresný model (obr. 2) je lineárny. Všetky koeficienty $(\beta)$ sú na základe $p$-hodnoty $t$-testu štatisticky významné. Chyba strednej hodnoty koeficientu $\beta_{0}$ dosahuje 27,60 . Chyby stredných hodnôt koeficientov $\beta_{1}$ a $\beta_{2}$ sú zanedbatel'né. S využitím $p$-hodnoty $(\sim 0,000) F$-testu $(\sim 97,95)$ považujeme regresný vzt'ah (11) za štatisticky významný. Daný model na základe koeficientu determinácie vysvetl'uje približne $73 \%$ rozdelenia. Pearsonov koeficient korelácie $\left(\sqrt{ } \mathrm{r}^{2}\right)$ na úrovni 0,83 naznačuje, že v rámci využitej regresnej funkcie je vel'mi silný pozitívny korelačný vzt’ah. Stredná chyba regresnej funkcie je 15,16. Mračno rezíduí vytvára približne kompaktný horizontálny tvar (obr. 3). Funkcia rezíduí síce získava tvar goniometrickej funkcie, avšak jej hodnoty sa pohybujú v blízkosti nulovej línie, čo je zo štatistického hl'adiska markantný znak.

Na základe všeobecného tvaru parabolického regresného vzt’ahu (3) bol odvodený vzt’ah (11) pre výpočet defoliácie pre každú hodnotu NSC2 komponentu. Výsledný obraz bol následne reklasifikovaný do desiatich kategórii podl'a tab. 4 (obr. 5/B).

$$
\text { defoliácia }=273,63+4,03862 * N S C 2+0,01502 * N S C 2^{2}
$$




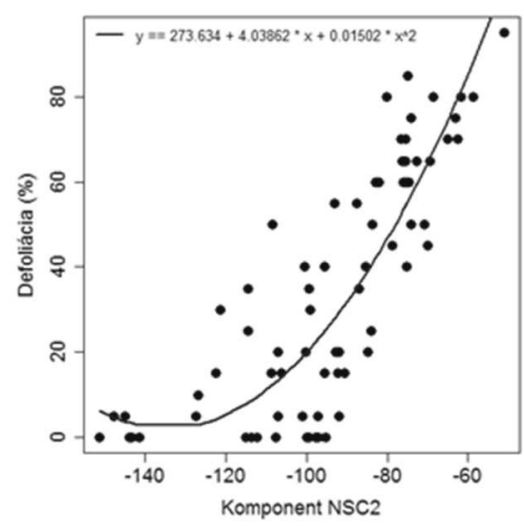

Obr. 2. Parabolická regresia - model

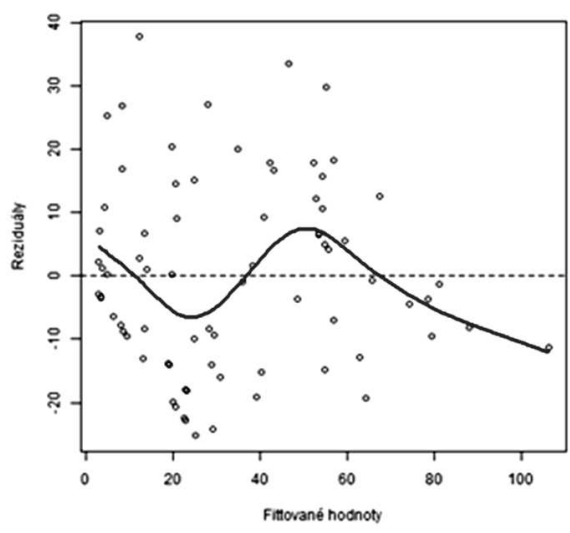

Obr. 3. Parabolická regresia - graf reziduálnych vs. fittovaných hodnôt

$\mathrm{Na}$ objektoch OBIA bol aplikovaný postup s využitím nástroja FSO (obr. 5, čast' C) a klasifikačný algoritmus SVM (obr. 5, čast' D).

Pre klasifikáciu s využitím nástroja FSO boli vypočítané objektové štatistiky zo vstupných vrstiev. V tab. 6 sú uvedené získané kombinácie vrstiev s nadobudnutou hodnotou spektrálnej odlišnosti.

Tab. 6. Kombinácie vrstiev a vypočítané euklidovské vzdialenosti

\begin{tabular}{|c|c|c|c|c|c|c|c|c|c|c|c|c|c|c|}
\hline 1 & $1 \mathrm{st}$ & & & & & & & & & & & & & 0,0211 \\
\hline 2 & $1 \mathrm{st}$ & ret & & & & & & & & & & & & 0,0926 \\
\hline 3 & $1 \mathrm{st}$ & ret & NSC1 & & & & & & & & & & & 0,1759 \\
\hline 4 & $1 \mathrm{st}$ & ret & NSC1 & GRVI & & & & & & & & & & 0,2234 \\
\hline 5 & $1 \mathrm{st}$ & ret & NSC1 & GRVI & Jas & & & & & & & & & 0,2462 \\
\hline 6 & $1 \mathrm{st}$ & ret & NSC1 & GRVI & Jas & IR & & & & & & & & 0,2568 \\
\hline 7 & $1 \mathrm{st}$ & ret & NSC1 & GRVI & Jas & IR & Max. Diff & & & & & & & 0,2648 \\
\hline 8 & $1 \mathrm{st}$ & ret & NSC1 & GRVI & Jas & IR & Max. Diff & G & & & & & & 0,2649 \\
\hline 9 & $1 \mathrm{st}$ & ret & NSC1 & GRVI & Jas & IR & Max. Diff & G & NSC2 & & & & & 0,2648 \\
\hline 10 & $1 \mathrm{st}$ & ret & NSC1 & GRVI & Jas & IR & Max. Diff & G & NSC2 & $\mathrm{R}$ & & & & 0,2613 \\
\hline 11 & $1 \mathrm{st}$ & ret & NSC1 & GRVI & Jas & IR & Max. Diff & G & NSC2 & $\mathrm{R}$ & $\mathrm{CI}_{\text {Green }}$ & & & 0,2512 \\
\hline 12 & $1 \mathrm{st}$ & ret & NSC1 & GRVI & Jas & IR & Max. Diff & G & NSC2 & $\mathrm{R}$ & $\mathrm{CI}_{\text {Green }}$ & SR & & 0,2417 \\
\hline 13 & $1 \mathrm{st}$ & ret & NSC1 & GRVI & Jas & IR & Max. Diff & G & NSC2 & $\mathrm{R}$ & $\mathrm{CI}_{\text {Green }}$ & SR & NDVI & 0,2327 \\
\hline
\end{tabular}

Vysvetlivky: 1st = DSM - prvý odraz, ret = raster intenzity odrazov, IR/R/G = spektrálne pásma multispektrálnej leteckej

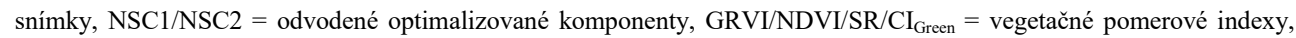
Max.diff/Jas (Brightness) = vrstvy odvodené softvérom eCognition.

Predpokladom pre klasifikáciu defoliácie pomocou algoritmu SVM bolo vyhl'adanie najvhodnejšej kombinácie údajových vrstiev (tab. 7), spoločne s vypočítaným Bray-Curtisovým spektrálnym indexom. Daný index má podl'a tab. 4 špecifikované dve klasifikačné kategórie, medzi ktorými bol dosiahnutý, pričom predstavuje najvhodnejšiu spektrálnu podobnost' v množine najviac podobných kategórií. 
Za najvhodnejšiu spektrálnu podobnost' považujeme takú podobnost', ktorá v rámci procesu vykazuje najnižšie hodnoty spektrálnej podobnosti v množine najviac podobných klasifikačných kategórií. Do množiny najviac podobných klasifikačných kategórií boli zaradené také kombinácie klasifikačných kategórií, ktoré $\mathrm{v}$ rámci všetkých možných kombinácií (bez opakovania) nadobudli najvyššiu hodnotu spektrálnej podobnosti.

Podl'a vypočítanej hodnoty defoliácie boli obrazové prvky zaradené do desiatich defoliačných kategórií a následne podl’a tab. 4 rozdelené do piatich tried poškodenia (obr. 4).

Tab. 7. Kombinácie vrstiev a Bray-Curtisov index podobnosti pre klasifikačné kategórie

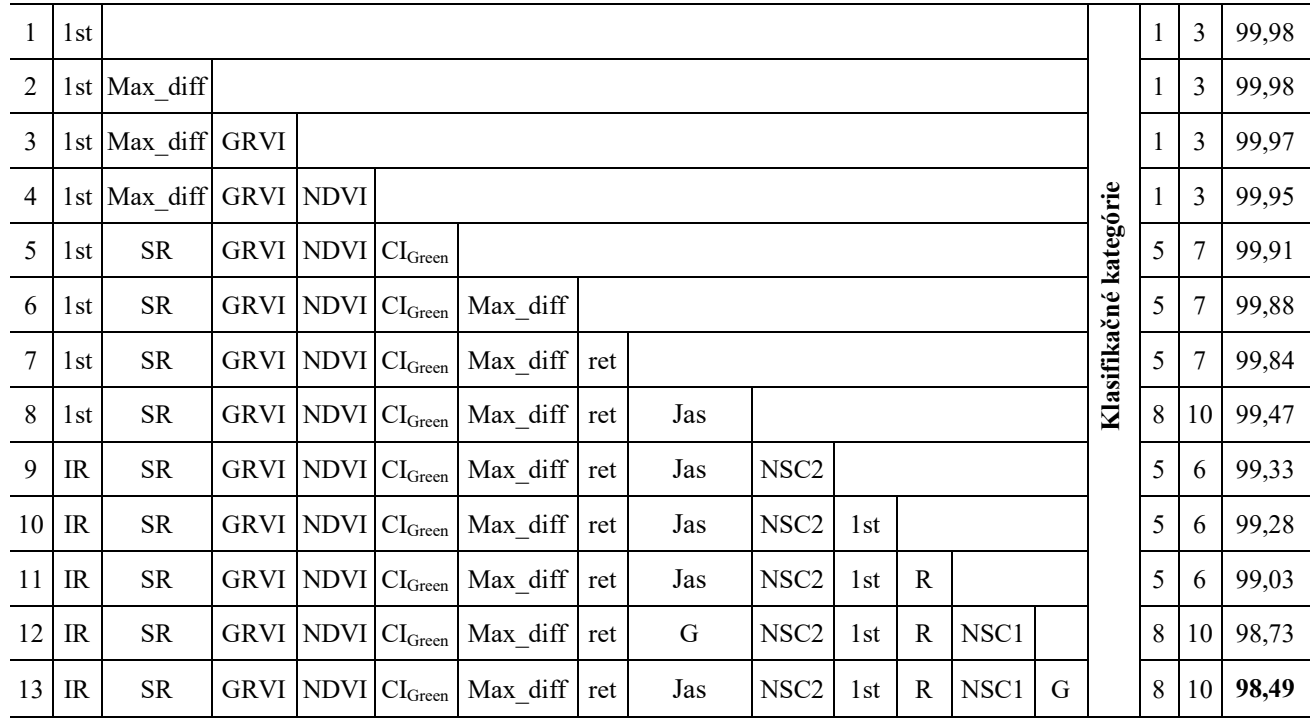

Vysvetlivky: 1st = DSM - prvý odraz, ret = raster intenzity odrazov, IR/R/G = spektrálne pásma multispektrálnej leteckej snímky, NSC1/NSC2 = odvodené optimalizované komponenty, GRVI/NDVI/SR/CI $I_{\text {Green }}$ = vegetačné pomerové indexy, Max.diff/Jas (Brightness) = vrstvy odvodené softvérom eCognition.

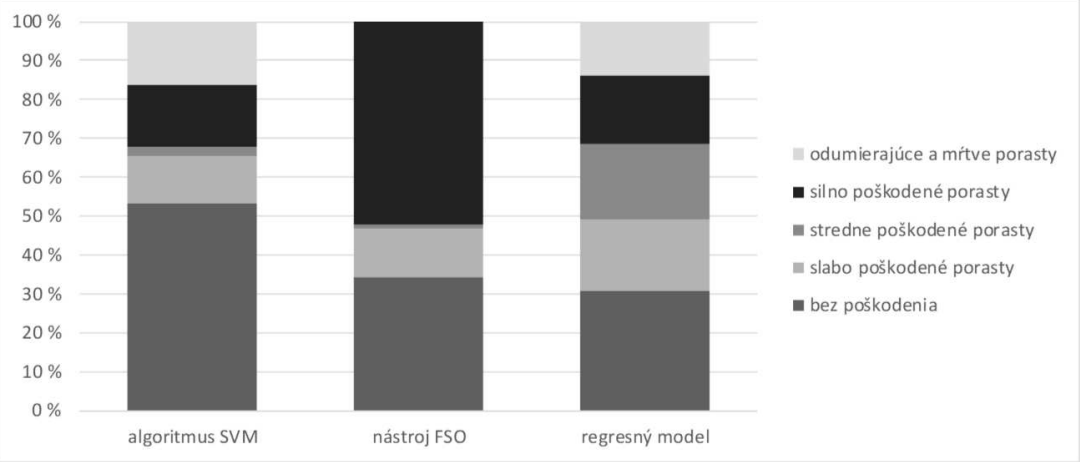

Obr. 4. Zdravotný stav korún stromov podl’a defoliačných tried poškodenia v závislosti od použitej metódy 

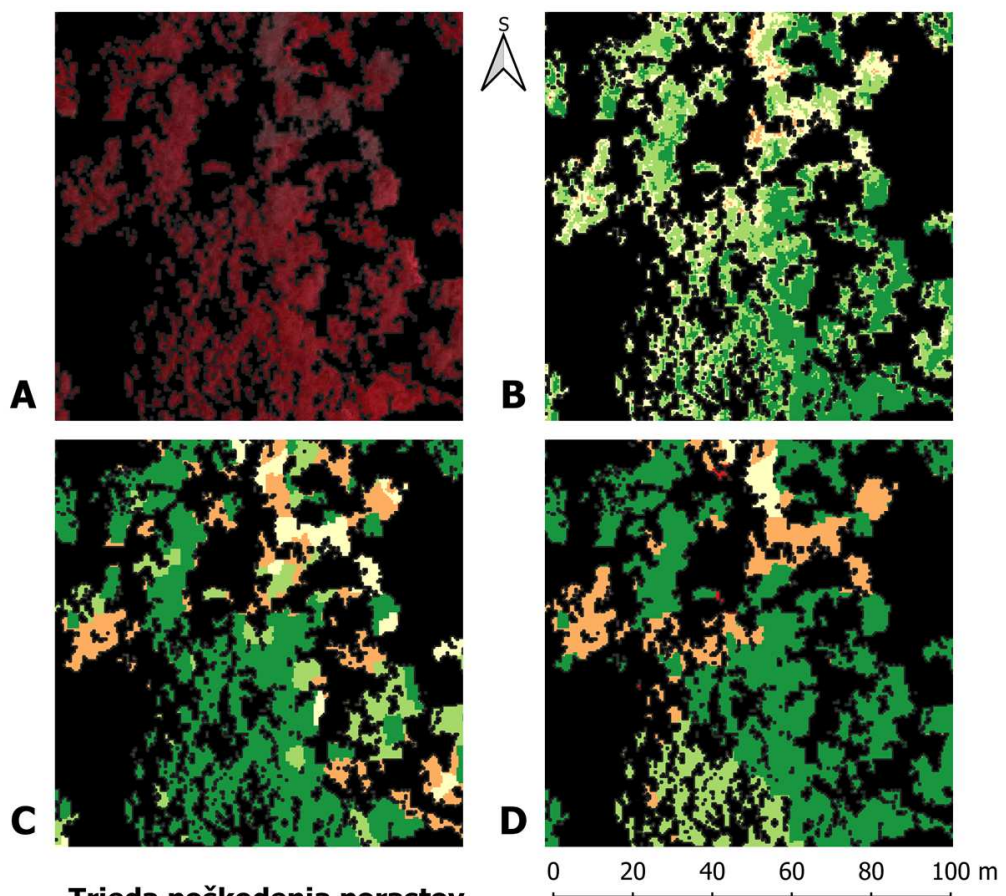

\section{Trieda poškodenia porastov \\ bez poškodenia \\ slabo poškodené porasty} stredne poškodené porasty

silno poškodené porasty

odmierajúce a mítve porasty

Obr. 5. Klasifikácia defoliácie na základe vybraných automatických metód

Vysvetlivky: A = multispektrálna snímka (IR $+R+G)$. Zdravé stromy v odtieňoch červenej, poškodené stromy v odtieňoch sivej podla stupňa poškodenia. $\mathrm{B}$ = raster defoliácie vypočítaný regresným modelom. $\mathrm{C}$ = raster defoliácie defoliácie odvodený nástrojom $\mathrm{FSO} . \mathrm{D}=$ raster defoliácie vypočítaný algoritmom SVM. Vo vysvetlivkách sú hodnoty defoliácie uvádzané v percentách (\%).
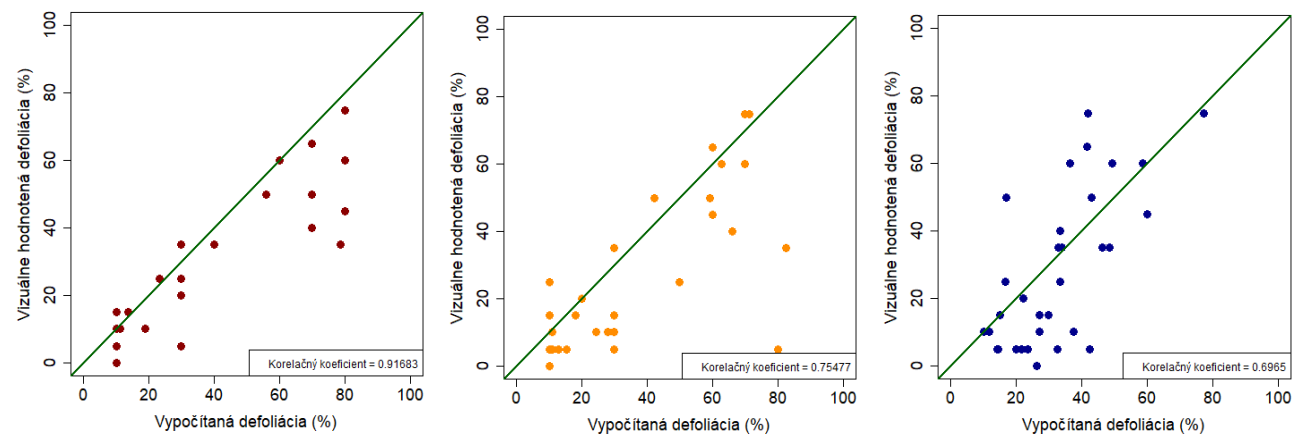

Obr. 6. Porovnanie vizuálne hodnotenej a vypočítanej defoliácie Vysvetlivky: algoritmus SVM (vl'avo), nástroj FSO (stred), regresný model (vpravo). 
Jednotlivé metódy výpočtu defoliácie sme porovnávali pomocou samostatne vytvoreného testovacieho súboru údajov s hodnotenou defoliáciou na vzorke 35 polygónov. Dané polygóny boli vytvorené vizuálnym hodnotením defoliácie stromov tak, aby sa nové polygóny nezhodovali s polygónmi vytvorenými v predchádzajúcich procesoch. Takto vytvorené polygóny a ich úroveň boli verifikované pri terénnej rekognoskácii. Zonálnym priemerom hodnôt pixelov priestorovo prislúchajúcich testovacej ploche vznikli párové hodnoty vizuálne hodnotenej a vypočítanej defoliácie (obr. 6).

Podl'a strednej chyby regresného vzt’ahu medzi vzniknutými párovými hodnotami považujeme metódu klasifikácie objektov OBIA s využitím algoritmu SVM (tab. 8) za najvhodnejšiu metódu klasifikácie defoliácie lesných porastov. Stredná chyba v tomto prípade vyjadruje absolútne percento straty asimilačných orgánov a zároveň určuje rámec odhadu. Sila nekauzálneho vzt’ahu medzi vypočítanou a vizuálne hodnotenou defoliáciou pri využívaní algoritmu je 0,92 , čo predstavuje vel'mi silnú pozitívnu asociáciu medzi sledovanými párovými premennými. Napriek tomu obr. 6 dokumentuje výrazné nadhodnotenie vypočítaných hodnôt defoliácie pri využívaní algoritmu SVM - najmä pri kategórii stredného poškodenia s defoliáciou hodnotenou na úrovni $41-60 \%$, pričom hodnoty sú v extrémnych prípadoch nadhodnotené až o tri defoliačné kategórie.

Tab. 8. Stredná chyba regresného vzt’ahu v závislosti od použitej metódy

\begin{tabular}{cc}
\hline Metóda & Stredná chyba regresného vzt’ahu v \% \\
\hline Algoritmus SVM & 9,32 \\
Regresný model & 16,76 \\
Nástroj FSO & 15,32 \\
\hline
\end{tabular}

Stredná chyba regresného vzt’ahu pri využívaní nástroja FSO, resp. regresného modelu, nadobúda približne rovnaké hodnoty (tab. 8). Napriek tomu je potrebné poukázat' na rozdielnu kompaktnost' výsledného mraku párovaných hodnôt. Hodnoty s využitím nástroja FSO - vypočítané hodnoty defoliácie (obr. 6/stred) konštantne nadhodnocujú o jednu, resp. dve defoliačné kategórie vo všetkých defoliačných triedach (bez zohl'adnenia výrazných štatistických extrémov). Daný fakt korešponduje s vypočítanou strednou chybou podl'a tab. 8. Analýzou metódy s využitím regresného modelu môžeme pozorovat' väčšiu kompaktnost' výsledného mračna bodov (obr. 6/vpravo), ale model hodnoty nadhodnocuje, najmä v prípade menej defoliovaných korún. Dôležité je však zdôraznit', že model v prípade silno poškodených korún už hodnoty vypočítanej defoliácie podhodnocuje - o približne dve defoliačné kategórie.

\section{DISKUSIA}

Spektrálne hodnoty počas vizuálnej interpretácie boli získavané v 2D prostredí. Tento fakt mohol výrazne ovplyvnit' kvalitu interpretácie, ked’že výsledné hodnoty mohli byt' bud' podhodnotené alebo nadhodnotené. Využívanie 2D prostredia je v súčasnosti nahrádzané využívaním stereomodelov, na základe ktorých sa defoliácia hodnotí jednoduchšie a presnejšie (napr. Bucha a Slávik 2013). Napriek tejto skutočnosti považujeme nami odhadnutú defoliáciu za dostatočne kvalitnú, aby tieto spektrálne hodnoty mohli byt' použité $\mathrm{v}$ procese tvorby optimalizovaných 
komponentov aj v procese odvodzovania regresného modelu. Toto tvrdenie nám potvrdzujú aj dostatočne silné nekauzálne vzt'ahy pri hodnotení kvality odvodených defoliačných modelov.

$\mathrm{V}$ procese tvorby masky lesa bol $\mathrm{v}$ prvom a druhom kroku kladený dôraz na vyčlenenie lesných/nelesných plôch s výraznou váhou lidarových údajov. Pri tret'om kroku bol algoritmus kontrastnej segmentácie využitý s ciel'om eliminovat' vplyv zatienených plôch na výsledky. Napriek kvalitným výstupom však bolo potrebné tieto homogénne plochy malej rozlohy odstránit'. Aplikácia vegetačných indexov nepreukázala dostatočné zlepšenie. To sme dosiahli až po aplikácii komponentu NSC1 v rámci algoritmu viacúrovňovej segmentácie.

$\mathrm{V}$ rámci štúdie sa ukázala problematickost' matematického vyhodnocovania vhodnosti spektrálnej odlíšitel'nosti jednotlivých defoliačných kategórií. Aplikácia Bray-Curtisovho indexu podobnosti preukázala, že v prípade nedostatočne spektrálne odlíšených kategórií nie je vhodná, ked'že vo všeobecnosti uvedený index dosahoval vel'mi vysoké hodnoty. Podobný záver však možno vyvodit' aj v rámci využívania nástroja FSO, ktorý taktiež nenadobúdal hodnoty, ktoré by indikovali výraznú spektrálnu odlišnost'. V súlade so štúdiou autorov Laliberte et al. (2010) odporúčame dané matematické vyhodnocovanie trénovacích množín aplikovat' najmä v prípade spektrálne výrazne odlíšitel'ných množín.

Metódy „blízkej fotogrametrie“ sú taktiež prínosom v oblasti dôslednejšej analýzy využitel'nosti jednotlivých vegetačných indexov. Dash et al. (2017) poukazujú na vysokú efektivitu rôznych indexov. Medzi najvhodnejšie vegetačné indexy nad'alej zarad'uje index NDVI, ktorý v ich štúdii aj pri vel'mi vysokom rozlíšení obrazových údajov vykazoval vel'mi dobré výsledky pri detekcii straty farebnosti listov spôsobených fyziologickým stresovými faktormi na skúmané stromy. Uvedená štúdia taktiež prezentuje kombináciu vegetačných indexov NDVI, RENDVI a NLI ako najvhodnejšiu pre modelovanie straty defoliačných orgánov stromov. Podl'a Dasha et al. (2017) sa najvhodnejšie priestorové rozlíšenie obrazových dát pri analýze defoliácie pohybuje v intervale od 1,5 - 2 metre. Špecifikácia priestorového rozlíšenia by však mala zohl'adňovat' dôkladnú identifikáciu skúmaného problému. $\mathrm{V}$ našom prípade preto považujeme nami zvolené priestorového rozlíšenie vstupných dát za vhodné.

Analýzou neparametrických klasifikačných algoritmov sa v kontexte defoliácie lesných porastov zaoberala štúdia autorov Otsu et al. (2018). Okrem iných klasifikačných algoritmov podrobne riešia problematiku algoritmov strojového učenia, medzi ktoré patria aj algoritmy Support Vector Machine (SVM) alebo Random Forest (RF). Tieto algoritmy odporúčajú využívat' najmä vtedy, ak má užívatel' $\mathrm{k}$ dispozícii dostatočne množstvo trénovacích plôch, ktoré okrem iného spĺn̆ajú aj špecifickú podmienku priestorovej vel'kosti. Túto priestorovú podmienku špecifikuje práca Colditza (2015), podporená štúdiou dvojice autorov Thanh a Kappas (2018) na úrovni aspoň $0,25 \%$ celkovej rozlohy analyzovanej plochy. Výsledky týchto štúdií dokumentujú vhodnost' využívania algoritmu SVM. V našom prípade sa stredná chyba regresného vzt'ahu pri využívaní algoritmu SVM pohybuje na úrovni okolo $9 \%$, čo korešponduje s hodnotami, ktoré pri analýze dosiahli Thanh a Kappas (2018), a to na úrovni približne $10 \%$. Taktiež poukazujú na fakt, že výsledky algoritmu RF boli signifikantne lepšie pri zväčšovaní plochy trénovacích areálov. Naopak, v prípade algoritmu SVM nedochádzalo k strmému nárastu krivky presnosti klasifikácie. Otsu et al. (2018) daný fakt potvrdzujú a v prípade obmedzených možností vytvárania trénovacích areálov (čo je aj prípad nami prezentova- 
nej štúdie) odporúčajú uprednostnit’ algoritmus SVM, ktorý vtedy dosahuje stabilnejšie a presnejšie výsledky.

Daný fakt potvrdzujú aj Sothe et al. (2017), ktorí považujú algoritmus SVM za vhodnejší v prípade nedostatočne spektrálne balansovaných dát. Naopak, čoraz častejšie využívaný algoritmus RF má tendenciu sa v prípade takýchto dát zameriavat' na klasifikáciu prevládajúcich a spektrálne jednoznačnejších tried, čo generuje menej presné výsledky pri nedostatočne spektrálne reprezentatívnych triedach. Nedostatočná spektrálna odlišnost' trénovacích plôch je detegovaná aj v rámci nášho príspevku, čo vytvorilo vhodné podmienky na aplikáciu algoritmu SVM.

\section{ZÁVER}

Hodnotenie zdravotného stavu lesných porastov patrí k vysoko aktuálnym témam výskumu lesnej krajiny. V tejto štúdii boli analyzované a hodnotené výsledky troch rôznych automatických metód hodnotenia defoliácie porastov s využitím leteckej multispektrálnej snímky a údajov z leteckého laserového skenovania. Najpresnejšie výsledky boli získané pomocou metódy OBIA s využitím algoritmu SVM. Stredná chyba hodnotenia absolútnej straty asimilačných orgánov dosahuje pri uvedenej metóde úroveň $9,32 \%$.

Preukázatel'ne vyššiu mieru chybovosti vykazovali výsledky získané pomocou nástroja FSO a regresného modelu. V prípade využívania nástroja FSO je to spôsobené nedostatočnými možnost’ami uživatel'a zasahovat' do samotného procesu klasifikácie alebo určovania použitej kombinácie vrstiev. Výsledky s využitím regresného modelu dosahujú porovnatel'né hodnoty ako práce podobného typu (napr. Bucha a Slávik 2013).

Z dôvodu, že defoliácia vypočítaná na objektoch OBIA je zonálne priemerovaná pre objekty, je výsledná hodnota defoliácie pre celý segment homogénna. Tento fakt je na jednej strane výhodný, ked’že reprezentuje stav celého alebo aspoň časti stromu. Na druhej strane avšak kladie významné požiadavky na proces delineácie korún, pričom vyžaduje dostatočne presné a podrobné vyčlenenie jednotlivých korún stromov v rámci homogénneho porastu.

Štúdia vytvára priestor na širšiu aplikáciu najoptimálnejšej metódy na rozsiahlejších územiach lužných lesov, prípadne aj v oblastiach iných typov listnatých alebo ihličnatých lesov. Práve komplexná evaluácia nami použitých metód na odhad defoliácie lesných porastov predstavuje významný poznatok pre optimalizáciu aktuálne používaných metód hodnotenia zdravotného stavu lesných porastov v širšom regióne. K vyššej presnosti hodnotenia zdravotného stavu lesov môže prispiet' aj využitie blízkej fotogrametrie vykonávanej pomocou bezpilotných lietajúcich prostriedkov (UAV), ktoré umožňujú analýzu takýchto porastov vo vel'kej mierke (Rusnák et al. 2018, Tomaštik et al. 2017). Možno preto predpokladat', že pri vel'mi vel'kom rozlíšení sa dá detegovat' strata asimilačných orgánov na úrovni jednotlivých konárov stromov. Prínosom tiež môže byt' využívanie hyperspektrálnych alebo radarových typov údajov získaných z leteckého monitorovania.

Príspevok vznikol vd'aka dátovej podpore NLC - LVÚ Zvolen v rámci medzinárodného projektu INMEIN (HUSK/1101/1.2.1/0141) a finančnej podpore projektu z programu VEGA (2/0096/16). 


\section{LITERATÚRA}

ADAM, E., MUTANGA, O., ODINDI, J., ABDEL-RAHMAN, E. M. (2014). Land-use/ cover classification in a heterogeneous coastal landscape using RapidEye imagery: evaluating the performance of random forest and support vector machines classifiers. International Journal of Remote Sensing, 35, 3440-3458. DOI: https:// doi.org/10.1080/01431161.2014.903435.

ADELABU, S., MUTANGA, O., ADAM, E. (2014). Evaluating the impact of red-edge band from Rapideye image for classifying insect defoliation levels. ISPRS Journal of Photogrammetry and Remote Sensing, 95, 34-41. DOI: https://doi.org/10.1016/ j.isprsjprs.2014.05.013.

BAGHDADI, N., ZRIBI, M. (2016). Optical Remote Sensing of Land Surface: Techniques and Methods. London (Elsevier).

BARNES, C., BALZER, H., BARRETT, K., EDDY, J., MILNER, S., SUARÉZ, J. C. (2017). Individual tree crown delineation from airborne laser scanning for diseased larch forest stands. Remote Sensing, 9, 231-250. DOI: https://dx.doi.org/10.3390/ rs9030231.

BRAY, J. R., CURTIS, J. T. (1957). An ordination of the upland forest communities of Southern Wisconsin. Ecological Monographs, 27, 325-349. DOI: https:// doi.org/10.2307/1942268.

BUCHA, T., BARKA, I., HLÁSNY, T., KONÔPKA, M., KOREŇ, M., LUKASOVÁ, V., LUKÁČ, M., OLSAVSKÁ, M., PAJTÍK, J., PAVLENDOVÁ, H., SITKOVÁ, Z., SNOPKOVÁ, Z., VLADOVIČ, J. (2014). Satelity v službách lesa. Zvolen (Slovak Academic Press).

BUCHA, T., SLÁVIK, M. (2013). Improved methods of classification of multispectral aerial photographs: evaluation of floodplain forests in the inundation area of the Danube. Folia Forestalia Polonica, 55, 58-71. DOI: https://doi.org/10.2478/ffp-2013-0007.

BUCHA, T., SLÁVIK, M., HATALA, N., BARTKO, M. (2013). Zhodnotenie zdravotného stavu lesov v inundačnej oblasti Dunaja v úseku Dobrohošt - Sap z leteckých multispektrálnych snímok z roku 2011. Lesnicky časopis - Foresty Journal, 59, 95-106. DOI: https://doi.org/10.2478/v10114-011-0021-z.

BUCHA, T., VLADOVIČ, J. (2000). Klasifikácia zdravotného stavu lesov pomocou kozmických snímok Landsat TM na modelovom území Lomnistej a Vajskovskej doliny. Lesnicky časopis - Forestry Journal, 46, 95-106.

COLDITZ, R. R. (2015). An evaluation of different training sample allocation schemes for discrete and continuous land cover classification using decision tree-based algorithms. Remote Sensing, 7, 9655-9681. DOI: https://dx.doi.org/10.3390/rs70809655.

DASH, J. P., WATT, M. S., PEARSE, G. D., HEAPHY, M., DUNGEY H. S. (2017). Assessing very high resolution UAV imagery for monitoring forest health during a simulated disease outbreak. ISPRS Journal of Photogrammetry and Remote Sensing, 131, 1-14. DOI: https://doi.org/10.1016/j.isprsjprs.2017.07.007.

EIGIRDAS, M., AUGUSTAITIS, A., MOZGERIS, G. (2013). Predicting tree crown defoliation using color-infrared orthophoto maps. iForest - Biogeosciences and Forestry, 6, 23-29. DOI: 10.3832/ifor0721-006.

EKSTRAND, S., SCHARDT, M., GRANICA, K., KOCH, B., KAHABKA, H., CARNEMOLLA, S., HÄUSLER, T. (1998). SAME FOR. Satellite based environmental monitoring of European forests. Luxembourg (European Communities).

FERANEC, J., OTAHEL', J., KOPECKÁ, M., NOVÁČEK, J., PAZÚR, R. (2018). Krajinná pokrývka Slovenska a jej zmeny v obdobi 1990 - 2012. Bratislava (Veda)

FÉRET, J. B., ASNER, G. P. (2013). Tree species discrimination in tropical forests using airborne imaging spectroscopy. IEEE Transactions on Geoscience and Remote Sensing, 51, 73-84. DOI: https://doi.org/10.1109/TGRS.2012.2199323.

FREITAS, S. R., MELLO, M. C. S., CRUZ, C. B. M. (2005). Relationships between forest structure and vegetation indices in Atlantic Rainforest. Forest Ecology and Management, 218, 353-362. DOI: https://doi.org/10.1016/j.foreco.2005.08.036. 
GÁBOR, M., KARLÍK, L., FALŤAN, V., PETROVIČ, F. (2017). Implementation of semiautomated object-based image land cover classification methods: a case study of the Male Karpaty Mts. (Slovakia). Geografický časopis, 69, 113-128.

GAMON, J. A., FIELD, C. B., GOULDEN, M. L., GRIFFIN, K. L., HARTLEY, A. E., JOEL, G., PENUELAS, J., VALENTINI, R. (1995). Relationships between NDVI, canopy structure, and photosynthesis in three Californian vegetation types. Ecological Applications, 5, 28-41. DOI: https://doi.org/10.2307/1942049.

GHOSH, A., FASSNACHT, F. E., JOSHI, P. K., KOCH, B. (2014). A framework for mapping tree species combining hyperspectral and LiDAR data: role of selected classifiers and sensor across three spatial scales. International Journal of Applied Earth Observation and Geoinformation, 26, 49-63. DOI: . https://doi.org/10.1016/j.jag.2013.05.017.

GITELSON, A. A., VIÑA, A., CIGANDA, V., RUNDQUIST, D. C., ARKEBAUER, T. J. (2005). Remote estimation of canopy chlorophyll content in crops. Geophysical Research Letters, 32, 1-4. DOI: https://doi.org/10.1029/2005GL022688.

GOGA, T., BOBÁL'OVÁ, H. (2017). Matematické princípy regresnej analýzy v geografickej perspektíve. Acta Geographica Universitatis Comenianae, 61, 241-256.

GRĂDINARU, S. R., KIENAST, F., PSOMAS, A. (2017). Using multi-seasonal Landsat imagery for rapid identification of abandoned land in areas affected by urban sprawl. Ecological Indicators, 96(2), 79-86. DOI: https://doi.org/10.1016/j.ecolind.2017.06.022.

GROSS, C. P. (2000). Remote sensing applications for forest health status assessment. Luxembourg (European Communities).

HAWRYŁO, P., BEDNARZ, B., WEZŻYK, K., SZOSTAK, M. (2018). Estimating defoliation of Scots pine stands using machine learning methods and vegetation indices of Sentinel-2. European Journal of Remote Sensing, 51, 194-204. DOI: https:// doi.org/10.1080/22797254.2017.1417745.

HEROLD, M., HANG, L. X., CLARKE, K. (2003). Spatial metrics and image texture for mapping urban land use. Photogrammetric Engineering and Remote Sensing, 69, 9911001. DOI: https://doi.org/10.14358/PERS.69.9.991.

CHANG, C. C. (2011). LIBSVM: a library for support vector machines. ACM Transactions on Intelligent Systems and Technology (TITS), 2, 1-27. DOI: https:// doi.org/10.1145/1961189.1961199.

CHEN, Q., BALDOCCHI, D., GONG, P., KELLY, M. (2006). Isolating individual trees in savanna woodland using small footprint Lidar data. Photogrammetric Engineering \& Remote Sensing, 8, 923-932. DOI: https://doi.org/10.14358/pers.72.8.923.

JACKSON, R. D. (1983). Spectral indices in N-space. Remote Sensing of Environment, 13, 409-421. DOI: https://doi.org/10.1016/0034-4257(83)90010-х.

JENSEN, J. R. (1986). Introductory digital image processing - a remote sensing perspective. New Jersey (University of South Carolina).

JORDAN, C. F. (1969). Derivation of leaf-area index from quality of light on forest floor. Ecology, 50, 663-666. DOI: https://doi.org/10.2307/1936256.

KMEŤ, J., BLAHO, J. (1996). Obsah fotosyntetických pigmentov v ihliciach smrekov (Picea abies /L./ Karst.) z rôznej nadmorskej výšky. Acta Facultatis Forestalis, 38, 29-38.

KUNCA, A., DUBEC, M., GALKO, J., GUBKA, A., KONÔPKA, B., KONÔPKA, J., LEONTOVYČ, R., LONGAUEROVÁ, V., MALOVÁ, M., NIKOLOV, CH., RELL, S., VAKULA, J., ZÚBRIK, M. (2018). Signalizačné správy o výskyte škodlivých činitel'ov v lesoch Slovenska. 2/2018, Národné lesnícke centrum - Lesnícky výskumný ústav, Zvolen, [Online]. Dostupné na: http://www.los.sk/pdf/sig maj18.pdf [cit: 6-72018].

LALIBERTE, A. S., BROWNING, D. M., RANGO, A. (2010). Feature selection methods for object-based classification of sub-decimeter resolution digital aerial imagery. Paper presented at the session of the GEOBIA 2010 Conference, Ghent, June 29-July 2, 2010.

LILLESAND, T., KIEFER, R. W., CHIPMAN, J. (2014). Remote sensing and image interpretation. New Jersey (Wiley). 
MARPU, P., NIEMEYER, I., NUSSBAUM, S., GLOAGUEN, R. (2008). A procedure for automatic object-based classification. In Blaschke, T., Lang, S., Hay, J. G., eds. Object based image analysis. Berlin (Springer), pp. 169-184. DOI: https://doi.org/10.1007/9783-540-77058-9 9.

MOTOHKA, T., NASAHARA, K. N., OGUMA, H., TSUCHIDA, S. (2010). Applicability of green-red vegetation index for remote sensing of vegetation phenology. Remote Sensing, 2, 2369-2387. DOI: https://doi.org/10.3390/rs2102369.

OTSU, K., PLA, M., VAYREDA, J., BROTONS, L. (2018). Calibrating the severity of forest defoliation by pine processionary moth with Landsat and UAV imagery. Sensors, 18(10), 1-14. DOI: https://doi.org/10.3390/s18103278.

PAVLENDA, P., PAJTÍK, P., PRIWITZER, T., CAPULIAK, J., KONÔPKA, M., KRUPOVÁ, D., PAVLENDOVÁ, D., SITKOVÄ, Z., ŠEBEÑ, V., TÓTHOVÁ, S. (2014). Monitoring lesov Slovenska. Správa za ĆMS Lesy za rok 2013. Zvolen (NLC - LVÚ Zvolen).

RAČKO, J. (1996). Fotoletecký monitoring zdravotného stavu lesov. Bratislava (Slovak Academic Press).

ROUSE. J. W., Jr., HAAS. R. H., SCHELL. J. A., DEERING. D. W. (1974). Monitoring vegetation systems in the Great Plains with ERTS. Third ERTS-1 Symposium. Washington, DC (NASA).

RUSNÁK, M., SLÁDEK, J., KIDOVÁ, A. (2018). Využitie UAV technológie pre klasifikáciu a mapovania krajiny vo fluviálnej geomorfológii. Geografický časopis, 70, 141160. DOI: https://doi.org/10.31577/geogrcas.2018.70.2.08.

Sothe, C., ALMEIDA, C. M. D., LIESENBERG, V., SCHIMALSKI, M. B. (2017). Evaluating Sentinel-2 and Landsat-8 data to map successional forest stages in a subtropical forest in Southern Brazil. Remote Sensing, 9, 838. DOI: https://doi.org/10.3390/ rs9080838.

SEDLIAK, M., SAČKOV, I., KULLA, L. (2017). Classification of tree species composition using a combination of multispectral imagery and airborne laser scanning data. Central European Forestry Journal, 63, 1-9. DOI: https://doi.org/10.1515/forj-20170002.

SCHEER, L'. (1997). A ssessment of forest conditions employing two-phased satellite remote sensing. Paper presented at the session of the Application of Remote Sensing in European Forest Monitoring. Wien, October 14-16, 1996.

SZEKIELDA, K. H. (1988). Satellite monitoring of earth resources. New Jersey (Wiley).

ŠMELKO, Š. (1990). Zist'ovanie stavu lesa kombináciou odhadu a merania dendrometrických veličín. Zvolen (VPA, VŠLD).

TARANTINO, E., FIGORITO, B. (2012). Mapping rural areas with widespread plastic covered vineyards using true color aerial data. Remote Sensing, 4, 1913-1928. DOI: https://doi.org/10.3390/rs4071913.

TIEDE, D., HOCHLEITNER, G., BLASCHKE, T. (2005). A full GISbased workflow for tree identification and delineation using laser scanning. The International Archives of Photogrammetry, Remote Sensing and Spatial Information Sciences, 36, 9-14.

THANH, N. P., KAPPAS, M. (2018). Comparison of random forest, k-nearest neighbour, and support vector machine classifiers for land cover classification using Sentinel-2 imagery. Sensors, 18. DOI: https://doi.org/10.3390/s18010018.

TOMASTTIK, J., MOKROŠ, M., SALON, S., CHUDÝ, F., TUNÁK, D. (2017). Accuracy of photogrammetric UAV - based point clouds under conditions of partially - open forest canopy. Forests, 8, 151-167. DOI: https://doi.org/10.3390/f8050151.

UN-ECE ICP Forests (2006). ICP Forests manual. Visual assessment of crown condition, including damage causes, [Online]. Dostupné na: https://www.icp-forests.org/pdf/ manual/2000/Chapt2 compl06.pdf [cit: 24-6-2018].

VAPNIK, V. N. (2013). The nature of statistical learning theory. New York (Springer).

WULDER, M. A., WHITE, J. C., COOPS, N. C., BUTSON, C. R. (2008). Multi-temporal analysis of high spatial resolution imagery for disturbance monitoring. Remote Sensing of Environment, 112, 2729-2740. DOI: https://doi.org/10.1016/j.rse.2008.01.010. 


\section{Tomáš Goga, Hana Bobál’ová, Ivan Sačkov, Monika Ko pecká \\ FOREST DAMAGE CLASSIFICATION IN LARGE SCALE BASED \\ ON AERIAL MULTISPECTRAL IMAGES AND LIDAR DATA: A CASE STUDY OF DUNAJSKÉ LUHY PROTECTED LANDSCAPE AREA}

In Slovakia, forests cover more than 2 million hectares (about $41 \%$ of area). Based on Corine Land Cover (CLC) data analysis, the forest landscape has been characterised by the most extensive changes within Slovakia over two last decades (Feranec et al. 2018). As in other European countries a significant increase in the deteriorated health status of forests has been observed in the last period (Kunca et al. 2018). A prerequisite for assessing the health status of forest stands and, in general, the sustainable development of forest communities could be the regular and correct processing of remote sensing data and their proper interpretation. The assessment of the state of health of forest stands is carried out in particular by estimating the degrees of defoliation, and respectively the depigmentation of assimilation organs of the trees. The leading indicators of the classification of damage to forest stands are the presence of dryers or very damaged trees. Defoliation can be caused by several stress factors (drought, lowered groundwater level, etc.). The effect of defoliation on the plant structure causes the susceptibility of the plant to tracheomycosis diseases or an attack by other biotic factors. The effect of stress factors has an impact on the cell structure and subsequent interaction of spectral reflection with the cell structure or chlorophyll.

The methodical procedure consisted of the steps as follows: visual interpretation of tree defoliation, deriving optimized components, defoliation calculation using a regression model, calculation of vegetation indices, creating Object-Based Image Analysis (OBIA) objects by image segmentation, defoliation calculation using the Feature Space Optimisation (FSO) tool, defoliation calculation using the Support Vector Machine (SVM) classification algorithm for OBIA objects and creation of a forest mask.

The evaluation of forest health conditions is one of the most up-to-date issues according to forest ecosystem research. In this study, we analysed and evaluated the result of three different automatic methods for the evaluation of defoliation using multispectral aerial photos and lidar data (Fig. 5). The most accurate results were obtained using the SVM algorithm for OBIA objects. The mean error (Tab. 8) of the absolute loss of assimilation organs is $9.32 \%$.

A demonstrably higher error rate was reported by the results from methods using FSO tool and regression model. In the case of using the FSO tool, this is due to insufficient user possibilities to interfere with the classification progress itself or to determine the combination of layers used. Results using the regression model achieve comparable values as the work of a similar type (e.g. Bucha and Slavík 2013).

The study showed the problem of numerical evaluation of the suitability of the spectral differentiation of individual defoliation categories. The application of the Bray-Curtis index of similarity has demonstrated that in the case of insufficiently spectrally differentiated categories, it is not appropriate. Supported also by the study Laliberte (2010), we recommend that the given numerical evaluation of the training sets is to be applied especially in the case of spectrally distinct sets.

Because defoliation is calculated for OBIA objects, the resulting defoliation value is homogeneous for the entire segment. This is, on the one hand, advantageous as it represents the state of the whole or at least part of the tree. However, on the other hand, there are significant requirements for the crown delineation process, demanding a sufficiently accurate and detailed detachment of individual tree crowns within a homogeneous plant. 
